\title{
Apolipoprotein E gene polymorphism is not a strong risk factor for diabetic nephropathy and retinopathy in Type I diabetes: case- control study Natalia S Shcherbak
}

\author{
Address: St.Petersburg State Medical University, Laboratory of Molecular Cardiology, L.Tolstoy St. 6/8, St.Petersburg, 197189, Russia \\ E-mail:nshch@yahoo.com
}

\author{
Published: 24 July 200I Received: 10 March 200I \\ BMC Medical Genetics 200I, 2:8 \\ Accepted: 24 July 2001
}

This article is available from: http://www.biomedcentral.com/147I-2350/2/8

(c) 200I Shcherbak; licensee BioMed Central Ltd. Verbatim copying and redistribution of this article are permitted in any medium for any non-commercial purpose, provided this notice is preserved along with the article's original URL. For commercial use, contact info@biomedcentral.com

\begin{abstract}
Background: The gene encoding apolipoprotein E (APOE) has been proposed as a candidate gene for vascular complications in Type I diabetes. This study aimed to investigate the influence of threeallelic variations in the APOE gene for the development of diabetic retinopathy and nephropathy.

Results: Neither APOE alleles frequencies or APOE genotypes frequencies differed between Type I diabetic groups either with or without nephropathy. Similar results were found for patients with and without diabetic retinopathy.

Conclusions: APOE gene polymorphism does not determine genetic susceptibility for the development of diabetic retinopathy in Type I diabetes patients. Association between APOE gene polymorphism and diabetic nephropathy may be weak or moderate, but not strong.
\end{abstract}

\section{Background}

Familial and epidemiological studies have indicated that there is a strong genetic component in the aetiology of diabetic nephropathy in Type I diabetes patients $[1,2]$. Apolipoprotein E (apoE) was discovered as a plasma protein involved in the metabolism of lipoproteins. Recently, the apolipoprotein E ( $A P O E$ ) gene has been suggested to be a risk factor for the development of micro- and macrovascular complications in diabetic patients.

The APOE gene is polymorphic. There are three common alleles, $E_{2}, E_{3}$, and $E_{4}$, which code for three major isoforms, resulting in six common genotypes [3,4]. Individuals with apoE2 have higher triglyceride levels and are associated with lower cholesterol compared to individuals with apoE3. Individuals with apoE4 often have elevated plasma cholesterol levels. There is an increased prevalence of cardiovascular disease and particularly Alzheimer's disease [5,6,7].

Apolipoprotein E polymorphism may influence the metabolism of lipoproteins in diabetic patients. Several recent studies have suggested that this polymorphism may be associated with a genetic predisposition for diabetic nephropathy $[8,9,10,11]$. Thus, $A P O E$ is an important candidate gene for the development of microvascular complications in Type I diabetes patients.

The aim of this study was to investigate the influence of $A P O E$ gene polymorphism in the development of diabetic nephropathy and retinopathy in Type I diabetes patients. 
Table I: Clinical characteristics by study groups

\begin{tabular}{|c|c|c|c|c|}
\hline & $\begin{array}{c}\text { Type I diabetes subjects } \\
\text { with nephropathy } \\
(\mathrm{DN}+)\end{array}$ & $\begin{array}{c}\text { Type I diabetes subjects } \\
\text { without nephropathy } \\
\text { (DN-) }\end{array}$ & $\begin{array}{c}\text { Type I diabetes subjects } \\
\text { with retinopathy } \\
(\mathrm{DR}+)\end{array}$ & $\begin{array}{c}\text { Type I diabetes subjects } \\
\text { without retinopathy } \\
\text { (DR-) }\end{array}$ \\
\hline Total subjects & 74 & 92 & 76 & 96 \\
\hline Age (years) & $25.1 \pm 11.9$ & $20.8 \pm 8.7$ & $29.8 \pm 10.1$ & $22.9 \pm 9.1$ \\
\hline \multicolumn{5}{|l|}{ Sex } \\
\hline (male/female) & $40 / 34$ & $40 / 52$ & $34 / 42$ & $50 / 46$ \\
\hline \multicolumn{5}{|l|}{ Diabetes } \\
\hline \multicolumn{5}{|l|}{ (years) } \\
\hline \multicolumn{5}{|l|}{ Diabetes onset } \\
\hline (years) & $11.1 \pm 6.2$ & $10.3 \pm 6.8$ & $12.2 \pm 8.1$ & $11.5 \pm 5.2$ \\
\hline $\mathrm{HbAIc}(\%)$ & $10.5 \pm 2.2$ & $9.8 \pm 1.9$ & $10.6 \pm 1.7$ & $9.9 \pm 1.7$ \\
\hline
\end{tabular}

Data are means $\pm S D$

\section{Materials and Methods \\ Patients}

In this study, all patients were Russians with unrelated Type I diabetes. All diabetic patients for the case-control study were recruited from St.Petersburg Diabetological Centres and had participated in the program "Diabetes mellitus" (which included monitoring of trends and examinations of the determinants of vascular complications in Type I diabetes) carried out in St. Petersburg, Russia since 1997.

The diabetic patients included in this study satisfied the World Health Organization criteria for diabetes mellitus [12]. Glycated haemoglobin ( $\mathrm{HbAlc}$ ) was measured by ion exchange chromatography [13]. At entry the patients had HbAlc levels of 5.7 to $16.8 \%$.

The Type I diabetes groups consisted of 74 subjects with nephropathy and 92 subjects without. The study covered 76 Type I diabetes patients with diabetic retinopathy and 96 patients without. Some subjects had more than one type of diabetic complication, and consequently were analysed in more than one group.

For Type I diabetes patients, all the information was examined for evidence of nondiabetic renal disease. Then questionnaires, medical records, and measurements of albumin excretion were used to determine whether they had diabetic nephropathy. Those patients were considered to have diabetic nephropathy if they were receiving treatment for renal disease and either suffered from persisting proteinuria, or had persisting high albuminuria. Urinary albumin excretion was measured by nephelometry [14]. Nephropathy was defined as a persistent urinary albumin excretion of more than $20 \mu \mathrm{g} / \mathrm{min}$, or 30 $\mathrm{mg} / 24 \mathrm{~h}$ in two out of three consecutive urinalyses. Indi- viduals with no history of nephropathy and no albumin excretion were considered free of nephropathy.

Fundus ophthalmoscopy and angiofluorography were used to diagnose retinopathy. The diabetic retinopathy group consisted of those showing retinal change, while Type I diabetes control group were those who showed no signs of retinopathy.

\section{DNA genotyping}

Blood was collected from each individual and stored in ethylenediaminetetraacetic acid (EDTA) tubes at $-20^{\circ} \mathrm{C}$. Genomic DNA was obtained from lysed white blood cells by phenol-chloroform extraction. The APOE gene polymorphism was detected by polymerase chain reaction (PCR). APOE genotyping was performed by the method of Hixson and Vernier [15] using a modified version described by Skobeleva et al. [16].

The sequence of the sense oligonucleotide primer was 5'AGATGCGGGCACGGCTGTTCAAGGA-3', and the antisense primer was 5'-CCCTCGCGAGCCCCGGCCTGGTACAC-3' [16]. Each amplification reaction contained 50 $\mathrm{mM} \mathrm{KCl}, 10 \mathrm{mM}$ tris- $\mathrm{HCl} \mathrm{pH} 8.4,1.5 \mathrm{mM} \mathrm{MgCl}_{2}, 0.25$ $\mu \mathrm{M}$ of each primer, $200 \mu \mathrm{M}$ dNTP, $10 \%$ DMSO, $0.1 \mu \mathrm{g}$ DNA and $1 \mathrm{U}$ Tag polymerase in a final volume of $20 \mu \mathrm{l}$. After denaturation step at $95^{\circ} \mathrm{C}$ for 5 minutes followed by 30 cycle of denaturation at $92^{\circ} \mathrm{C}(1 \mathrm{~min})$, annealing at $64^{\circ} \mathrm{C}(1 \mathrm{~min})$, extension at $72^{\circ} \mathrm{C}(1.5 \mathrm{~min})$ and a final extension at $72^{\circ} \mathrm{C}(5 \mathrm{~min})$ using a MiniCycler (MJ Research, Watertown, MA, USA). Genotypes were determined by Hin61 (Fermentas, Vilnius, Lithuania) digestion of a 244-base pair PCR-amplified fragment spanning the two polymorphic sites. The digested DNA fragments were separated using migration on $12 \%$ polyacrylamide gels and visualized under UV illumination af- 
Table 2: Distributionof APOE genotypes and alleles in the case-control association study

\begin{tabular}{|c|c|c|c|c|c|c|}
\hline & $\begin{array}{l}\text { Type I diabetes subjects } \\
\text { with nephropathy } \\
(\mathrm{DN}+) \\
\mathrm{n}(\%) \\
\mathrm{m} / \mathrm{f}(\% / \%)\end{array}$ & 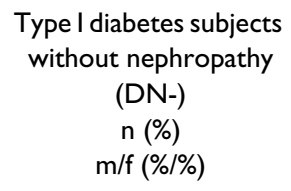 & $P$ value & $\begin{array}{l}\text { Type I diabetes subjects } \\
\text { with retinopathy } \\
(\mathrm{DR}+) \\
\mathrm{n}(\%) \\
\mathrm{m} / \mathrm{f}(\% / \%)\end{array}$ & $\begin{array}{c}\text { Type I diabetes subjects } \\
\text { without retinopathy } \\
\text { (DR-) } \\
\mathrm{n}(\%) \\
\mathrm{m} / \mathrm{f}(\% / \%)\end{array}$ & $P$ Value \\
\hline & $74(100)$ & $92(100)$ & & $76(100)$ & $96(100)$ & \\
\hline \multirow[t]{3}{*}{ Total subjects } & $40 / 34$ & $40 / 52$ & & $34 / 42$ & $50 / 46$ & \\
\hline & $(54.0 / 46.0)$ & $(43.5 / 56.5)$ & & $(44.7 / 55.3)$ & $(52.1 / 47.9)$ & \\
\hline & & $2(2.2)$ & & & $\mathrm{I}(\mathrm{I} .0)$ & \\
\hline \multirow[t]{3}{*}{ E2E2 } & 0 & $0 / 2$ & NS & 0 & $0 / 1$ & NS \\
\hline & & $(0 / 3.8)$ & & & $(0 / 2.2)$ & \\
\hline & $48(64.9)$ & $54(58.7)$ & & $45(59.2)$ & $61(63.6)$ & \\
\hline \multirow[t]{3}{*}{ E3E3 } & $25 / 23$ & $27 / 27$ & NS & $21 / 24$ & $33 / 28$ & NS \\
\hline & $(62.5 / 67.6)$ & $(67.5 / 51.9)$ & & $(61.8 / 57.1)$ & $(66.9 / 60.9)$ & \\
\hline & & & & & $I(I .0)$ & \\
\hline \multirow[t]{3}{*}{ E4E4 } & 0 & 0 & NS & 0 & $0 / 1$ & NS \\
\hline & & & & & $(0 / 2.2)$ & \\
\hline & $13(17.6)$ & $20(21.7)$ & & 18(23.7) & $16(16.7)$ & \\
\hline \multirow[t]{3}{*}{ E2E3 } & $8 / 5$ & $5 / 15$ & NS & $9 / 9$ & $6 / 10$ & NS \\
\hline & $(20.0 / 14.7)$ & $(12.5 / 28.8)$ & & $(26.4 / 21.4)$ & $(12.0 / 21.7)$ & \\
\hline & $3(4.0)$ & & & $3(3.9)$ & $I(I .0)$ & \\
\hline \multirow[t]{3}{*}{ E2E4 } & $0 / 3$ & 0 & NS & $0 / 3$ & $1 / 0$ & NS \\
\hline & $(0 / 8.9)$ & & & $(0 / 7.2)$ & $(2.0 / 0)$ & \\
\hline & $10(13.5)$ & $16(17.4)$ & & $10(13.2)$ & $16(16.7)$ & \\
\hline \multirow[t]{3}{*}{ E3E4 } & $7 / 3$ & $8 / 8$ & NS & $4 / 6$ & $10 / 6$ & NS \\
\hline & $(17.5 / 8.8)$ & $(20.0 / 15.5)$ & & (II.8/14.3) & $(20.0 / 13.0)$ & \\
\hline & $16(10.8)$ & $24(13.0)$ & & $21(13.8)$ & $19(9.9)$ & \\
\hline \multirow[t]{3}{*}{ E2 } & $8 / 8$ & $5 / 19$ & NS & $9 / 12$ & $7 / 12$ & NS \\
\hline & $(10.0 / 11.8)$ & $(6.3 / 18.3)$ & & $(13.2 / 14 / 3)$ & $(7.0 / 13.0)$ & \\
\hline & $119(80.4)$ & I44(78.3) & & $118(77.6)$ & I54(80.2) & \\
\hline \multirow[t]{3}{*}{ E3 } & $65 / 54$ & $67 / 77$ & NS & $55 / 63$ & $82 / 72$ & NS \\
\hline & $(81.3 / 79.4)$ & $(83.7 / 74.0)$ & & $(80.9 / 75.0)$ & $(82.0 / 78.3)$ & \\
\hline & $13(8.8)$ & $16(8.7)$ & & $13(8.6)$ & $19(9.9)$ & \\
\hline \multirow[t]{2}{*}{ E4 } & $7 / 6$ & $8 / 8$ & NS & $4 / 9$ & $11 / 8$ & NS \\
\hline & $(8.7 / 8.8)$ & $(10.0 / 7.7)$ & & $(5.9 / 10.7)$ & (II.0/8.7) & \\
\hline \multirow[t]{3}{*}{ Total chromosomes } & $148(100)$ & $184(100)$ & & $152(100)$ & $192(100)$ & \\
\hline & $80 / 68$ & $40 / 104$ & & $68 / 84$ & $100 / 92$ & \\
\hline & $(54.1 / 45.9)$ & $(43.5 / 56.5)$ & & $(44.7 / 55.3)$ & $(52.1 / 47.9)$ & \\
\hline
\end{tabular}

NS, not significant ( $P$ value $>0.05)$

ter ethidium bromide staining [16]. The codominant alleles E2, E3, and E4 determine the six APOE genotypes.

\section{Statistical testing}

All data are presented as means \pm SD. Groups were compared using the Student's $t$ test for comparison of two groups for quantitative variables. Allele frequency among control subjects and case subjects were compared using standard $\mathrm{X}^{2}$ tests. The difference in genotype fre- quencies between the groups was tested by Fisher's exact test. A value of $\mathrm{P}<0.05$ was considered significant.

\section{Results}

Clinical characteristics by study group are shown in Table 1 . No significant difference was seen between groups with vascular complications (nephropathy and retinopathy) and those without, no matter the age, diabetes duration, age at diabetes onset, and mean HbAlc. 
The frequency of each genotype in each group conformed to the Hardy -Weinberg equilibrium.

The distribution of the $A P O E$ genotypes is shown in Table 2. There was no significant difference in $A P O E$ genotype and allele frequency between nephropathic and normoalbuminuric diabetic patients. In this study, no association was found between diabetic retinopathy and $A P O E$ polymorphisms. APOE allele frequencies for males and females were similar within groups and in different groups.

\section{Discussion}

Diabetic nephropathy and diabetic retinopathy are the two most important microangiopathic complications in Type I diabetic patients. Many of the environmental factors that influence the risk of vascular disease are known, but genetic components of the risk for diabetic microangiopathy are poorly understood. Several candidate genes have been investigated to elucidate the genetic factors responsible for vascular complications. The most important of these are the aldose reductase gene (ALR2) [17], the insertion/deletion (I/D) polymorphism of the angiotensin I - converting enzyme $(A C E)$ gene [18,19], C825T polymorphism of the gene encoding the beta-3 subunit of geterotrimeric G-proteins $(G N B 3)[20,21,22]$, and $\mathrm{C} 677 \mathrm{~T}$ polymorphism of the methylenetetrahydrofolate reductase gene (MTHFR) [23].

The genetic polymorphism of apolipoprotein $\mathrm{E}$ is associated with lipid abnormalities. Eto et al. [9] suggested that lipid abnormalities may contribute to the development and progression of kidney disease, including diabetic nephropathy. The $E_{2}$ allele frequency was significantly higher in Type II diabetes patients with nephropathy (7.2\%) and with renal failure (9.7\%) than in diabetic patients without nephropathy (2.6\%) [9]. Apolipoprotein E polymorphism is associated with the progression of diabetic nephropathy. Presence of the apolipoprotein $E_{4}$ allele is a protective factor, and other alleles entail risk factors [24].

The genes responsible for genetic predisposition to vascular complications are still unknown, and little is known about the molecular basis of these complications. The influence of the $A P O E$ gene polymorphism to the development of diabetic microangiopathy is uncertain. Chowdhury et al. [10] and Araki et al. [11] demonstrated an association between the presence of the APOE E2 allele and diabetic nephropathy in Caucasian patients with Type I diabetes, although some investigators do not support this association $[25,26]$.

This study elucidated the role of $A P O E$ gene polymorphism in the predisposition to diabetic vascular compli- cations. No association of $A P O E$ gene polymorphism with diabetic nephropathy was demonstrated. This result for diabetic nephropathy confirms the findings of Tarnow et al. [25] and Onuma et al. [26]. It should be mentioned that sample sizes in $[10,11]$ were larger than in this study. With increased sample size comes the possibility to demonstrate an association. But the larger the necessary and sufficient minimal sample size, the weaker the association demonstrated.

We also analysed the association of the $A P O E$ gene polymorphism with diabetic retinopathy in the present study. No significant differences were found between groups with and without this vascular complication. A similar result has been shown by Tarnow et al. [25] for diabetic retinopathy.

\section{Conclusions}

The present study found no evidence for a role of the $A P O E$ gene polymorphism in genetic susceptibility for the development of diabetic retinopathy in Type I diabetes patients. Association between APOE gene polymorphism and diabetic nephropathy may be weak or moderate, but not strong.

\section{COMPETING INTERESTS}

None declared.

\section{Acknowledgements}

This work was supported by grant M00-2.6K-359 from Competitive Centre of Basic Science (St.Petersburg, Russia).

The author thanks Dr. A.S.Stroikova (St.Petersburg Diabetic Centre, St.Petersburg, Russia) for her valuable consultation and verification of patients' clinical information.

The author can not but mention agitated discussions with Prof. E.I.Schwartz (St.Petersburg Paediatric Medical Academy, St.Petersburg, Russia).

The author wishes to thank reviewers Dr. S.Bain and Dr. A.Demaine for careful reading and helpful comments on the manuscript.

Special thanks to J.Fletcher (Redraft.com, Maidenhead, UK) for redrafting in part and H.Kidd, Ph.D. (Bioscience Editors - GWE, Akarp, Sweden) for editing in part.

\section{References}

I. Andersen AR, Christiansen JS, Andersen JK, Kreiner S, Deckert T: Diabetic nephropathy in Type I (insulin dependent) diabetes: an epidemiological study Diabetologia I983, 25:496-50|

2. Quinn M, Angelico MC, Warram JH, Krolewski AS: Familial factors determine the development of diabetic nephropathy in patients with IDDM Diabetologia 1996, 39:940-945

3. Utermann G, Langenbeck $U$, Beisiegel U, Weber W: Genetics of the apolipoprotein $\mathbf{E}$ system in man Am J Hum Genet 1980, 32:339-347

4. Zannis VI, Breslow JL: Human very low density lipoprotein apolipoprotein $E$ isoprotein polymorphism is explained by genetic variation and posttranslational modification Biochemistry 1981, 20:1033-1041

5. Reilly SL, Ferrell RE, Kottke BA, Kamboh MI, Sing CF: The genderspecific apolipoprotein $E$ genotype influence on the distribution of lipids and apolipoproteins in the population of Ro- 
chester, MN. I. Pleiotropic effects on means and variances Am J Hum Genet I99I, 49: I I55-II 66

6. Xhignesse M, Lussier-Cacan S, Sing CF, Kessling AM, Davignon J: Influences of common variants of apolipoprotein $E$ on measures of lipid metabolism in a sample selected for health Arterioscler Thromb 1991, I I: I 100-1 I I0

7. Bickeboller H, Campion D, Brice A, Amouyel P, Hannequin D, Didierjean 0, Penet C, Martin C, Perez-Tur J, Michon A, et al: Apolipoprotein $E$ and Alzheimer disease: genotype-specific risks by age and sex Am J Hum Genet 1997, 60:439-446

8. Ukkola 0, Kervinen K, Salmela PI, von DickhoffK, Laakso M, Kesaniemi YA: Apolipoprotein $E$ phenotype is related to macro- and microangiopathy in patients with non-insulin-dependent diabetes mellitus Atherosclerosis 1993, 101:9-15

9. Eto M, Horita K, Morikawa A, Nakata H, Okada M, Saito M, Nomura M, Abiko A, Iwashima Y, lkoda A, et al: Increased frequency of apolipoprotein epsilon 2 allele in non-insulin dependent diabetic (NIDDM) patients with nephropathy Clin Genet 1995, 48:288-292

10. Chowdhury TA, Dyer PH, Kumar S, Gibson SP, Rowe BR, Davies S, Marshall SM, Morris PJ, Gill GV, Feeney S, et al: Association of apolipoprotein epsilon2 allele with diabetic nephropathy in Caucasian subjects with IDDM Diabetes 1998, 47:278-280

II. Araki S, Moczulski DK, Hanna L, Scott LJ, Warram JH, Krolewski AS: APOE polymorphisms and the development of diabetic nephropathy in type I diabetes: results of case-control and family-based studies Diabetes 2000, 49:2190-2195

12. Diabetes Mellitus WHO Technical Report Series 1985, 727. World Health Organization, Geneva.

13. Jeppsson JO, Jerntorp P, Sundkvist G, Englund H, Nylund V: Measurement of hemoglobin Alc by a new liquid-chromatographic assay: methodology, clinical utility, and relation to glucose tolerance evaluated Clin Chem 1986, 32:1867-1872

14. Marre M, Claudel JP, Ciret P, Luis N, Suarez L, Passa P: Laser immunonephelometry for routine quantification of urinary albumin excretion Clin Chem 1987, 33:209-2I3

15. Hixson JE, Vernier DT: Restriction isotyping of human apolipoprotein $E$ by gene amplification and cleavage with Hhal $J$ Lipid Res 1990, 31:545-548

16. Skobeleva NA, Vasina VI, Volkova MV, Sverdlova AM, Fomicheva EV, Obraztsova GI, Talalaeva El, Shakir K, Laasri M, Vorontsov IM, et al: DNA polymorphism of the APOB I00, APOCIII, APOE, and angiotensin-converting enzyme genes and indicators of the lipid spectrum in children and adolescents in St. Petersburg Mol Gen Mikrobiol Virusol I997, 4:36-40

17. Heesom AE, Hibberd ML, Millward A, Demaine AG: Polymorphism in the ${ }^{5}$ '-end of the aldose reductase gene is strongly associated with the development of diabetic nephropathy in type I diabetes Diabetes 1997, 46:287-291

18. Doria A, Warram JH, Krolewski AS: Genetic predisposition to diabetic nephropathy. Evidence for a role of the angiotensin I - converting enzyme gene Diabetes 1994, 43:690-695

19. Ha SK, Seo JK: Insertion/deletion polymorphism in ACE gene as a predictor for progression of diabetic nephropathy Kidney Int Suppl 1997, 60:S28-S32

20. Fogarty DG, Zychma MJ, Scott LJ, Warram JH, Krolewski AS: The C825T polymorphism in the human G-protein beta3 subunit gene is not associated with diabetic nephropathy in Type I diabetes mellitus Diabetologia 1998, 4I:1304-1308

21. Siffert W: G protein beta3 subunit $825 \mathrm{~T}$ allele, hypertension, obesity, and diabetic nephropathy Nephrol Dial Transplant 2000, I5:1298-1306

22. Shcherbak NS, Schwartz El: The C825T polymorphism in the Gprotein $\beta 3$ subunit gene and diabetic complications in IDDM patients Journal of Human Genetics 200I, 46: I88-191

23. Shcherbak NS, Shutskaya ZhV, Sheidina AM, Larionova VI, Schwartz El: Methylenetetrahydrofolate Reductase Gene Polymorphism as a Risk Factor for Diabetic Nephropathy in IDDM Patients Molecular Genetics and Metabolism 1999, 68:375-378

24. Kimura H, Suzuki Y, Gejyo F, Karasawa R, Miyazaki R, Suzuki S, Arakawa M: Apolipoprotein E4 reduces risk of diabetic nephropathy in patients with NIDDM Am J Kidney Dis 1998, 31:666-673

25. Tamow L, Stehouwer CD, Emeis J], Poirier 0, Cambien F, Hansen BV: Parving HH: Plasminogen activator inhibitor-I and apolipoprotein E gene polymorphisms and diabetic angiopathy Nephrol Dial Transplant 2000, 15:625-630
26. Onuma T, Laffel LM, Angelico MC, Krolewski AS: Apolipoprotein E genotypes and risk of diabetic nephropathy J Am Soc Nephrol 1996, 7:1075-1078

\section{Pre-publication history}

The pre-publication history for this paper can be accessed here:

http://www.biomedcentral.com/content/backmatter/ 1471-2350-2-8-b1.pdf

Publish with BioMedcentral and every scientist can read your work free of charge

"BioMedcentral will be the most significant development for disseminating the results of biomedical research in our lifetime." Paul Nurse, Director-General, Imperial Cancer Research Fund

Publish with BMC and your research papers will be:

- available free of charge to the entire biomedical community

- peer reviewed and published immediately upon acceptance

- cited in PubMed and archived on PubMed Central

- yours - you keep the copyright

Submit your manuscript here:

http://www.biomedcentral.com/manuscript/ 